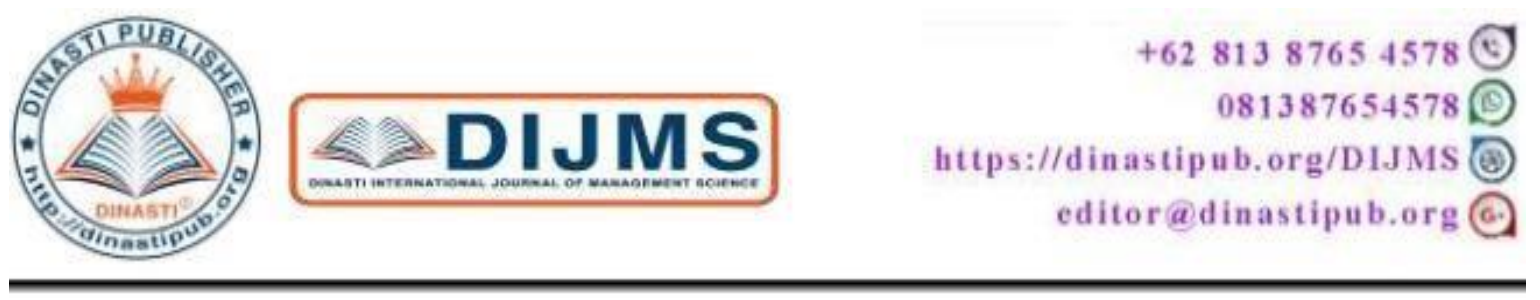

\title{
THE EFFECT OF PERCEIVED ORGANIZATIONAL SUPPORT AND WORKLOAD ON JOB SATISFACTION THROUGH WORK-SCHOOL CONFLICT AS A MEDIATING VARIABLE
}

Feri Lubis ${ }^{1)}$, Mafizatun Nurhayati ${ }^{2)}$

${ }^{1), 2)}$ Master of Management, Mercu Buana University, Jakarta, Indonesia

\begin{tabular}{|c|c|}
\hline $\begin{array}{l}\text { ARTICLE INFORMATION } \\
\text { Received: } 12 \text { January } 2020 \\
\text { Revised : } 15 \text { January } 2020 \\
\text { Issued : } 18 \text { January } 2020\end{array}$ & $\begin{array}{l}\text { Abstract: This study aims to examine and analyze } \\
\text { the effect of perceived organizational support and } \\
\text { workload on job satisfaction through work school } \\
\text { conflict as a mediating variable. Respondent data is } \\
\text { taken from Master students with status as employees } \\
\text { who study at universities that have A accreditation } \\
\text { in DKI Jakarta. The sampling method used in this } \\
\text { study was purposive sampling. The population is } \\
\text { taken using the Hair method in which the number } \\
\text { of indicators is multiplied (5-15) (53 x 5) so that } 265 \\
\text { samples are obtained). The analytical method used } \\
\text { in this study is SEM-PLS 3.0. The results showed } \\
\text { that the perception of organizational support had a } \\
\text { positive and significant effect on satisfaction but did } \\
\text { not affect work school conflict. Workload has a } \\
\text { negative effect on satisfaction and a positive and } \\
\text { significant effect on work school conflict. Work } \\
\text { school conflict plays a role in mediating the effect } \\
\text { of perceived organizational support on job } \\
\text { satisfaction. In addition, workload plays a role in } \\
\text { mediating the effect of perceived organizational } \\
\text { support on job satisfaction } \\
\text { Keywords: Perception of organizational support, } \\
\text { workload, job satisfaction, work school conflict }\end{array}$ \\
\hline
\end{tabular}

\section{INTRODUCTION}

Facing the current of globalization, the potential of human resources (HR) must be utilized as well as possible so as to be able to provide optimal output, therefore organizations must think of ways that can be done to develop their employees in order to encourage the progress of the organization in order to jointly achieve organizational goals . One of the main aspects of human resource management is the measurement of employee job satisfaction. 
Robbins and Judge (2015) state that job satisfaction is a positive feeling about work that results from an evaluation of its characteristics. Someone with high job satisfaction has positive feelings about their work, while someone with a low level has negative feelings.

According to the spector in Baliarti (2016) states that job satisfaction describes how someone feels about their work and other aspects of their work. Someone will be satisfied with the work done if it is as expected. Other aspects besides the job occur when the employee has other activities outside his work such as continuing his Masters level while remaining an employee. The division of roles as employees and students makes both roles performed not optimal so that what is done is not as expected. This creates a feeling of dissatisfaction. The emergence of employee job dissatisfaction can be seen from the results of the questionnaire distributed by researchers.

Based on the Pre survey conducted to 30 respondents conducted to Master students who were employees, the following results were obtained:

Table 1. Pre-survey Data of Permanent Employees with Status as Masters Students

\begin{tabular}{llll}
\hline No. & \multicolumn{1}{c}{ Questions } & Yes & No \\
\hline 1. & $\begin{array}{l}\text { Are you not satisfied } \\
\text { with the level of your } \\
\text { career advancement? }\end{array}$ & \\
& & \\
\hline $2 . \quad$ & $\begin{array}{l}\text { Can a Masters degree } \\
\text { make it easier for you } \\
\text { to get promoted? }\end{array}$ & \\
& \multicolumn{3}{l}{$23 \%$} \\
\hline $3 . \quad \begin{array}{l}\text { Is a Masters degree a } \\
\text { prerequisite for } \\
\text { promotion } \\
\text { loccupying certain } \\
\text { positions in your } \\
\text { company? }\end{array}$ & \\
\end{tabular}

Source: Primary Data, processed by Researchers (2019)

Based on the pre-survey data in Table 1.1 above, $80 \%$ of employees who are pursuing Master degree studies are not satisfied with the level of career advancement they are currently getting. 77\% of employees continue Master degree to facilitate promotion in the company. And $53 \%$ of companies apply master's degrees to occupy certain positions in the company. Dissatisfaction is what underlies employees to continue their Master degree studies. This is what underlies the increasing number of employees who pursue Master degree studies. 
Table 2. Data of University Graduates in Indonesia 2014 - 2017 (in thousands)

\begin{tabular}{|c|c|c|c|}
\hline \multirow{2}{*}{ Year } & & & \\
\hline & S1 & S2 & S3 \\
\hline $2014 / 2015$ & 47,2 & 90 & 41,5 \\
\hline $2015 / 2016$ & 46,8 & $\begin{array}{c}106 \\
3\end{array}$ & 119,9 \\
\hline $2016 / 2017$ & 41,5 & $\begin{array}{c}119, \\
9\end{array}$ & 21,8 \\
\hline
\end{tabular}

Source: Antara, Pangkalan Data pendidikan Tinggi, Kemenristek-Dikti (2018)

Based on Table 2, the population of Indonesians who continue to Masters level has increased every year. Many residents already hold bachelor's degrees, making the situation more competitive and difficult to find work. Continuing to study at the Masters level makes someone superior to undergraduate graduates, especially in getting a higher position in an organization.

Based on PraSurvey conducted to Master degree students regarding the reasons for continuing Master level study and choosing to study while working. PraSurvey was filled by 30 respondents from Universities in the Jakarta area that were Accredited A with the following results:

Table 3. Prasurvey Reasons for Lecture while Working

\begin{tabular}{|c|c|c|c|}
\hline $\begin{array}{c}\text { No } \\
\text {. }\end{array}$ & Quetions & Information & $\begin{array}{c}(\% \\
)\end{array}$ \\
\hline \multirow[t]{2}{*}{1} & \multirow{2}{*}{$\begin{array}{l}\text { Reasons } \\
\text { for } \\
\text { continuin } \\
\text { g Master } \\
\text { degree } \\
\text { study }\end{array}$} & $\begin{array}{l}\text { Career } \\
\text { improvement }\end{array}$ & $\begin{array}{l}60 \\
\% \\
\end{array}$ \\
\hline & & $\begin{array}{l}\text { Add } \\
\text { knowledge }\end{array}$ & $\begin{array}{l}40 \\
\%\end{array}$ \\
\hline \multirow[t]{2}{*}{2} & \multirow{2}{*}{$\begin{array}{l}\text { Expenses } \\
\text { incurred } \\
\text { while } \\
\text { undergoin } \\
\text { g roles as } \\
\text { students } \\
\text { and } \\
\text { employee }\end{array}$} & Cost & $\begin{array}{l}77 \\
\% \\
\end{array}$ \\
\hline & & Role conflict & $\begin{array}{l}23 \\
\%\end{array}$ \\
\hline
\end{tabular}

Source: Primary Data, processed by Researchers (2019)

Based on the pre-survey data in Table 3 above, there are a number of reasons they suggest to continue Master level. One of the reasons for continuing Masters level that arises from the data above is to improve their careers in the organizations where they work. In Government Agencies, BUMN (State-Owned Enterprises), even in private companies, to occupy a certain level of position requires $\mathrm{S} 2$ graduates as the main requirements they require. This is certainly an opportunity for several universities, especially in Jakarta to open postgraduate or graduate classes. The high interest of someone to continue their master's degree 
has made several universities in Jakarta competing to open extension classes or employee classes. Masters students, who generally have worked, need a University that is able to provide time that suits their schedule and of course the quality and accreditation is recognized. Continuing graduate studies and being an employee, a dual role conflict problem arises.

The emergence of problems that occur due to the dual role conflict between roles as employees and students is called the work-school conflict (WSC). WSC refers to a situation where students who work at a company will reduce their ability, energy, and time to meet the demands of the school / university (Park \& Sprung, 2013). WSC is defined through the extent to which work can interfere with the ability of employees to meet demands and responsibilities related to school (Andrade, 2018).

The results of research Hair Jr. (2014) states that role conflict influences job satisfaction. this is not in line with research conducted by Goodarzi (2015) and Hatami (2015) which states that role conflict negatively affects job satisfaction.

Pranata research results (2016) states that workload has a positive and significant effect on job satisfaction. this is not in line with research Purbaningrat and Surya (2015) which states that workload negatively affects job satisfaction. Palupi's research (2009) states that the dual role or WSC has a positive effect on workload. Where the higher the workload the higher the WSC. The existence of a positive relationship between the WSC with each variable, making researchers place the WSC as a mediating variable to strengthen the relationship between variables.

The results of the research of Rifki \& Arijo (2015), Kneight \& Leimer (2010), Baranik et al (2010), Kartika \& Sagung (2018) stated that the perception of organizational support (perceived organizational support) had a positive effect on satisfaction. This is not in line with research conducted by Zumrah (2013) which states there is no significant relationship between POS and job satisfaction. The results of Hanifia's research (2018) state that the perception of organizational support has a positive effect on the dual role or WSC. The existence of a positive relationship between the WSC with each variable, making researchers place the WSC as a mediating variable to strengthen the relationship between variables.

Based on the background of the problem, this research is focused on the following problems:

- Does the perception of organizational support affect job satisfaction.

- Does workload affect job satisfaction.

- Does the effect of perceived organizational support influence work school conflict.

- Does the effect of workload affect work school conflict.

- Does work school conflict affect job satisfaction.

- Does work school conflict play a role in mediating the effect of perceived organizational support on job satisfaction.

- Does work school conflict play a role in mediating the effect of workload on job satisfaction.

\section{LITERATURE REVIEW}

\section{Perceived Organizational Support}

According to Eisenberger et al in Wikendari (2011), the perception of organizational support is the perception of employees about the extent to which organizations assess their contributions and care about their well-being. The perception of organizational support can be measured by dimensions namely: fairness, superiors' support, as well as rewards and working conditions. 


\section{Workload}

According to (Tarwaka, 2015), workload is a level of loading that is too high allowing excess energy usage and "overstres", on the contrary the optimum loading intensity that exists between these two extreme limits and of course varies between individuals from one individual to another. Workload can be measured by dimensions namely: the burden of time, the burden of mental effort, and the burden of psychological stress.

\section{Work School Conflict}

According to Olson in Andrade (2018), work school conflict is defined through the extent to which work can interfere with the ability of employees to meet demands and responsibilities related to school. work school conflict can be measured by dimensions namely: time based conflict, strain based condliction, and behavior based conflict.

\section{Job Satisfaction}

According to Robbins in Pradana (2017), job satisfaction is a general attitude towards one's work, which shows the difference between the number of awards received by workers and the amount they believe they should receive. Job satisfaction can be measured by dimensions namely: salary, promotion, coworkers, promotions, and the work itself.

Based on the formulation of the problem and empirical studies that have been carried out, it can be withdrawn, The following hypothesis:

H1: Perceived Organizational Support is thought to have a positive and significant effect on Job Satisfaction

According to Robbins (2008) perceived organizational support is the degree to which employees believe the organization appreciates employee contributions and cares about employee welfare. This shows that individuals feel the organization provides support when rewards are considered fairly, employees feel they have a voice in decision making and there is support from direct superiors. If organizational support is positive and organizational commitment is strong, job satisfaction will increase.

H2: Workload negatively affects job satisfaction.

According to Munandar (2012) workload is a condition of work with job descriptions that must be completed at a certain time limit. Jobs that do not look at the working hours of each employee cause dissatisfaction with employees. Workload arises due to differences between the capacity or ability of workers with the work demands that must be faced. Since human work is mental and physical in nature, each has a different level of loading.

\section{H3: Perceived organizational support has a negative effect on Work School Conflict}

According to Rhoades \& Eisenberger, in Endah (2015), the perception of organizational support refers to employees' perceptions of the extent to which organizations assess contributions, provide support, and care for employee welfare.

H4: Workload has a positive and significant effect on Work School Conflict

In a study conducted by Sohaib Raza et al 2017 it was found that to reduce role conflict, the burden given to employees needs to be reduced in accordance with the position held by the 
employee. Because the many double burdens held by employees have an impact on the high role conflict that occurs. The existence of employees who continue Master level and the status is still an employee, of course, raises a double burden as a result of the dual role that is carried out. This was found in the results of Palupi (2009) where a dual role or Work School Conflict had a positive relationship with workload. Where the higher the workload the higher the Work School Conflict.

H5: Work School Conflict negatively affects job satisfaction.

Multiple role conflict is one of the factors that influence satisfaction, where more and more dual role conflict arises in a person, the lower job satisfaction. This was found in research conducted by Goodarzi (2015).

This is consistent with research conducted by Hair Jr. (2014) where the result of role conflict has an effect on job satisfaction, this also supports research conducted by Hatami (2015) who found that dual role conflict has a negative effect on job satisfaction.

H6: Work School Conflict is able to play a role in mediating the perception of organizational support for job satisfaction.

In a study conducted by Rifki (2015) the perception of high organizational support makes job satisfaction increase. As well as research conducted by Babic (2015) where the higher the perception of organizational support, the fewer dual role conflicts that arise. However, research conducted by (Kahya, 2014) found that an increase in dual role conflict arises, which decreases the perceived level of organizational support. Robbin (2008) suggests that the higher the perception of organizational support, the higher the level of satisfaction and vice versa, the decline in the perception of organizational support results in a decrease in employee job satisfaction.

This is consistent with research conducted by Arijo (2015), Kneight and Leimer (2010), Baranik et al (2010), Kartika (2018), Sagung (2018) where the Perception of Organizational Support has a positive and significant effect on satisfaction.

Supported by research conducted by Stinglhamber (2015), and Hansez (2015) where there is a positive relationship between Perception of Organizational Support and Work School Conflict. However, research conducted by (Hojjat et al, 2015) shows a negative relationship between dual role conflict and job satisfaction and research conducted by (Kahya, 2014) shows a negative relationship between perceived organizational support and multiple role conflict.

H7: Work School Conflict is able to play a role in mediating workload on job satisfaction.

In a study conducted by Purbaningrat and Surya (2015), high workloads made work satisfaction low. In research conducted by (Goodarzi, 2015) the emergence of a dual role (work school conflict) makes the level of job satisfaction even lower. This makes the workload positively influences work school conflicts. So that (work school conflict) plays a role in mediating the influence of negative relationships between workload and satisfaction.

This is in accordance with research conducted by Surya (2015) found that workload has a negative and significant effect on job satisfaction. Mahendrawan and Indrawati (2015) also 
found that workload had a negative and significant effect on employee job satisfaction. This is in line with research conducted by Courtney Laughman1 et al (2016) where Work school conflict negatively affects job satisfaction. As well as research conducted by Hera et al where workload positively influences work school conflict.

H6: Work School Conflict is able to play a role in mediating the perception of organizational support for job satisfaction.

Based on the description above, the conceptual framework is made as follows:

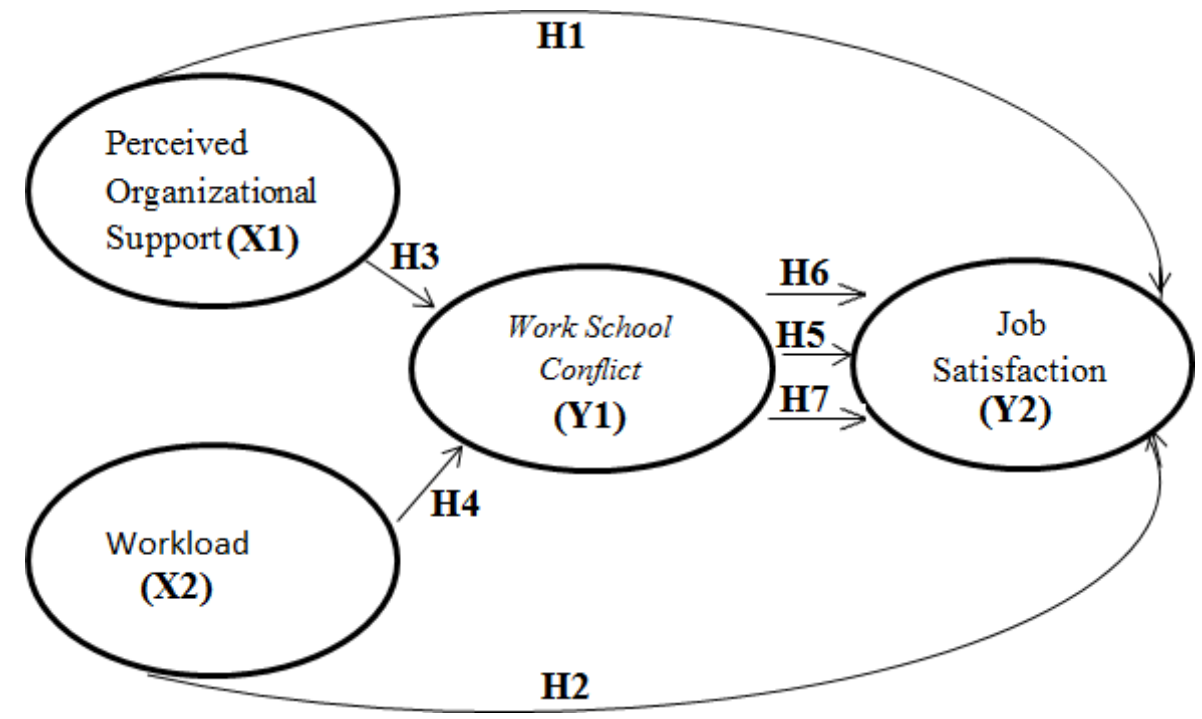

Figure 1. Conceptual Framework

\section{RESEARCH METHODS}

This type of research is causality research, namely research that aims to test hypotheses and find out the relationship and influence between two or more variables on other variables. This study aims to examine the effect of the independent variable, namely, the perception of organizational support and workload on the dependent variable, namely work school conflict and job satisfaction.

This study uses two types of variables, namely independent variables and dependent variables. work school conflict (Y1) and job satisfaction (Y2) in this study serve as the dependent variable. Perception of organizational support (X1) and workload (X2) as an independent variable, then the measurement method and scale of each variable related in this study to support success in the research to be conducted.

This research is a type of applied research with quantitative analytical analysis. Quantitative research methods can be interpreted as research methods based on the philosophy of positivism, used to examine specific populations or samples. The sample is part of the number and characteristics possessed by the population or in other words the sample is part of the population that is expected to represent the study population. The sampling method used is the purposive sampling method, where sampling is adjusted to the required sample requirements. In this study the determination of the sample takes into account the strata (levels) 
available in the population that is employees who have permanent status in a company and the employee also has the status of a Master student at A accredited University in DKI Jakarta.

\section{FINDINGS AND DISCUSSION}

The method of data analysis in this study uses SEM (Structural Equation Model) using the PLS program. (Partial Least Square) is an alternative model of SEM-based covariance.

\section{Loading Factor}

The loading factor value used in this study is $>0.50$ so that if the loading factor value $<0.50$ on the calculation results of the measurement model (outer model) will be removed from the model. After testing the loading factor the resulting instrument was more than $>0,50$.

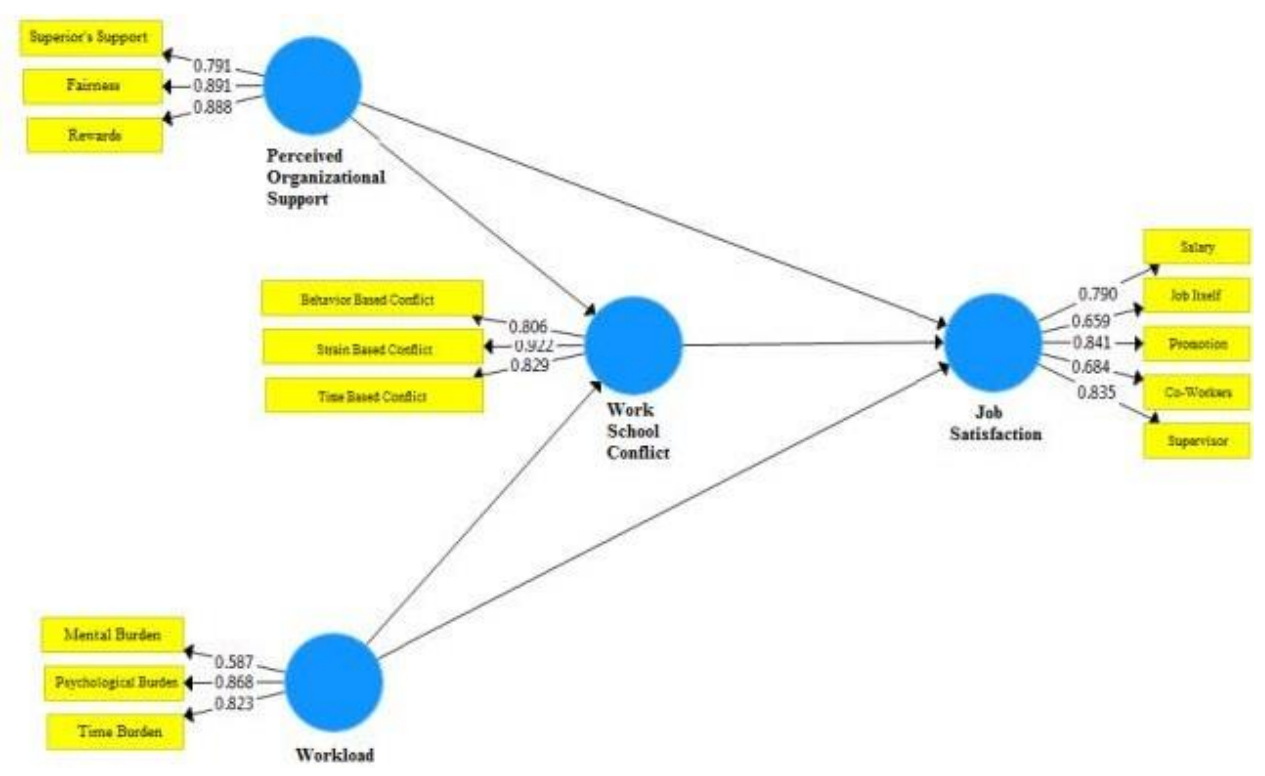

Figure 2. Loading Factor Instrument Test Results

\section{Average variance extracted (AVE)}

Evaluation of convergent validity from the examination of Average Variance Extracted (AVE) can be seen from the value of AVE based on the results of data processing with SmartPLS version 3.0 as described in Table 4.1.

Table 4. Value of Average Variance Extracted (AVE) for Each Variable

\begin{tabular}{lc}
\hline \multicolumn{1}{c}{ Variable } & $\begin{array}{c}\text { Average Variance } \\
\text { Extracted (AVE) Value }\end{array}$ \\
\hline $\begin{array}{l}\text { Perceived Organization } \\
\text { Support }\end{array}$ & 0,585
\end{tabular}

$\begin{array}{ll}\text { Workload } & 0,504 \\ \text { Work School Conflict } & 0,565 \\ \text { Job Satisfaction } & 0,508\end{array}$

Source: researchers processed data (2019) 
In table 4 above it is known that the value of AVE for all variables has a value of AVE $>0.5$, namely 0.585 each for Organizational Support Perception, 0.504 for workload, 0.565 for Work School Conflict, and 0.508 for Job Satisfaction.

\section{Discriminant Validity Test}

\section{Cross Loading}

Cross loading is the correlation coefficient of the indicator to its construct compared to the correlation coefficient with other constructs. The correlation coefficient value of the indicator must be greater on the construct than the other constructs. The results are shown in table 5 .

Tabel 5. Descriminant Validity Test

\begin{tabular}{|c|c|c|c|c|c|}
\hline Dimension & Workload & $\begin{array}{l}\text { Perceived } \\
\text { Organizational } \\
\text { Support }\end{array}$ & $\begin{array}{l}\text { Job } \\
\text { Satisfaction }\end{array}$ & $\begin{array}{l}\text { Work } \\
\text { School } \\
\text { Conflict }\end{array}$ & Information \\
\hline Mental Burden & 0,587 & 0,159 & 0,135 & 0,227 & Valid \\
\hline Psicologycal Burden & 0,868 & 0,069 & 0,087 & 0,508 & Valid \\
\hline Time Burden & 0,823 & 0,043 & 0,068 & 0,421 & Valid \\
\hline Superior's Support & 0,088 & 0,791 & 0,428 & $-0,008$ & Valid \\
\hline Faimess & 0,075 & 0,891 & 0,614 & $-0,069$ & Valid \\
\hline Rewards & 0,096 & 0,888 & 0,568 & $-0,069$ & Valid \\
\hline Salary & 0,031 & 0,483 & 0,790 & $-0,184$ & Valid \\
\hline Working Itself & 0,095 & 0,306 & 0,659 & $-0,027$ & Valid \\
\hline Promotion & 0,107 & 0,595 & 0,841 & $-0,108$ & Valid \\
\hline coworkers & 0,078 & 0,379 & 0,684 & $-0,098$ & Valid \\
\hline Supervisor & 0,123 & 0,582 & 0,835 & $-0,050$ & Valid \\
\hline $\begin{array}{l}\text { Behavior Based } \\
\text { Conflict }\end{array}$ & 0,397 & $-0,100$ & $-0,180$ & 0,806 & Valid \\
\hline $\begin{array}{l}\text { Strain Based } \\
\text { Conflict }\end{array}$ & 0,500 & $-0,018$ & $-0,093$ & 0,922 & Valid \\
\hline Time Based Conflict & 0,449 & $-0,045$ & $-0,051$ & 0,829 & Valid \\
\hline
\end{tabular}

Based on the results of discriminant validity testing in table 5 above, it shows that all indicators have a cross loading value to the construct greater than the value of the cross loading to other constructs so that it is declared valid. It can be concluded that the construct of Organizational Support Perception, workload, Work School Conflict, and Job Satisfaction has good discriminant validity.

\section{AVE Root}

Tabel 6.AVE Root Value

\begin{tabular}{lcc}
\hline \multicolumn{1}{c}{ Variable } & $\begin{array}{c}\text { AVE } \\
\text { Value }\end{array}$ & AVE Root Value \\
\hline $\begin{array}{l}\text { Perceived Organization } \\
\text { Support }\end{array}$ & 0,585 & 0,765 \\
Workload & 0,504 & 0,710 \\
Work School Conflict & 0,565 & 0,752 \\
Job Satisfaction & 0,508 & 0,713
\end{tabular}

Source: researchers processed data (2019) 
Table 7. Correlation of Latent Variables

\begin{tabular}{|l|l|l|l|l|}
\hline \multicolumn{1}{|c|}{ Indicator } & Workload & $\begin{array}{c}\text { Job } \\
\text { Sarisfaction }\end{array}$ & $\begin{array}{c}\text { Perceived } \\
\text { Organizational } \\
\text { Support }\end{array}$ & $\begin{array}{c}\text { Work } \\
\text { School } \\
\text { Conflict }\end{array}$ \\
\hline Workload & 0,710 & & & \\
\hline Job Sarisfaction & 0,091 & 0,713 & & \\
\hline $\begin{array}{l}\text { Perceived } \\
\text { Organizational Support }\end{array}$ & 0,071 & 0,660 & 0,765 & \\
\hline Work School Conflict & 0,545 & $-0,140$ & $-0,060$ & 0,752 \\
\hline
\end{tabular}

Source: researchers processed data (2019)

The results in Table 6 and Table 7 show the Root Value of AVE > Correlation of latent variables so that they are declared valid.

\section{Reliability Test (Cronbach's Alpha dan Composite Reliability)}

\begin{tabular}{|c|c|c|}
\hline Variable & $\begin{array}{l}\text { Cronbach's } \\
\text { Coefficient } \\
\text { Alpha }\end{array}$ & $\begin{array}{l}\text { Composite } \\
\text { Reability } \\
\text { (CR) }\end{array}$ \\
\hline $\begin{array}{l}\text { Perceived Organization } \\
\text { Support }\end{array}$ & 0,880 & 0,907 \\
\hline Workload & 0,798 & 0,856 \\
\hline Work School Conflict & 0,912 & 0,928 \\
\hline Job Satisfaction & 0,902 & 0,918 \\
\hline
\end{tabular}

Source: researchers processed data (2019)

As shown in table 8 it is known that the Cronbach's Coefficient Alpha value and composite reliability for the variables studied are Organizational Support Perception, workload, Work School Conflict, and Job Satisfaction more than 0.6 or even close to 1 and the Composite reliability (CR) value more than 0.85 . These values have exceeded the standard, respectively $>0.6$ and $>0.7$, so that all variables in the study are declared reliable.

\section{Inner Model Test}

\section{A. Goodness of Fit Index (GoF) Test}

The purpose of testing the Goodness of Fit Index $(\mathrm{GoF})$ is to validate the combined performance of the measurement model (outer model) and the structural model (inner model) obtained through calculations as follows:

$$
\begin{aligned}
& \mathrm{GoF}=\sqrt{\operatorname{AVExR^{2}}} \\
& \mathrm{GoF}=\sqrt{0,54 \times 0,141}
\end{aligned}
$$


$\mathrm{GoF}=\sqrt{0,07614}$

$\mathrm{GoF}=0,2759$

Information :

$\mathrm{AVE}=(0,585+0,504+0,565+0,508) / 4$

$=2,16 / 4$

$=0,54$

$\mathrm{R}$ square $=(0,307 \times 0,460) / 2=0,141$

The results of the Goodness of Fit Index (GoF) calculation showed a value of 0.2759. Based on these results it can be concluded that the combined performance of the measurement model (outer model) and structural model (inner model) as a whole is good because the Goodness of Fit Index (GoF) value is more than 0.25 (moderate scale).

\section{R Square $\left(\mathbf{R}^{2}\right)$}

To evaluate the value of $\mathrm{R}^{2}$ based on the results of calculations using calculate SmartPLS version 3.0, the results of the $\mathrm{R}^{2}$ value are 0.307 for the work school conflict variable and 0.460 for the job satisfaction variable. The value of $\mathrm{R}^{2}$ indicates that the level of determination of exogenous variables (perceived organizational support and workload) towards the endogenous is quite high.

The simultaneous effect of the variable perception of organizational support and workload on Work School Conflict (Y1) can be done by calculating f arithmetic / f statistics using the formula as below.

a. $\mathrm{R}^{2}=0,307(\mathrm{Y} 1)$

$$
\begin{array}{ll}
\text { F arithmatic } & =\frac{\frac{R^{2}}{(k-1)}}{1-R 2 /(n-k)} \\
\text { F arithmatic } & =\frac{0.307}{(4-1)} \\
\text { F arithmatic } & =0,10 / 0,0,0026 \\
\text { F arithmatic } & =38,46
\end{array}
$$

The simultaneous effect of compensation variables, work climate and work motivation on Employee Performance (Y2) can be done by calculating f arithmetic / $\mathrm{f}$ statistics using the formula as below.

b. $\mathrm{R}^{2}=0,460(\mathrm{Y} 2)$

$$
\begin{aligned}
\text { F arithmatic } & =\frac{R^{2}}{1-R 2 /(n-k)} \\
\text { F arithmatic } & =\frac{0.460}{(4-1)} \\
\text { F arithmatic } & =0,15 / 0,060 /(265-4) \\
\text { F arithmatic } & =75
\end{aligned}
$$


Significant test results were simultaneously used to test hypotheses 1 and 2 in this study. The calculated $F$ value in this study is 38.46 and 75 the table's $F$ value (df $1=4-1$; df $2=265$ 4) alpha 0.05 is 2.64. This means that $\mathrm{f}$ count $>\mathrm{f}$ Table (2.64), then $\mathrm{H} 2$ and $\mathrm{H} 2$ are accepted and Ho is rejected.

\section{Predictive Relevance $\left(Q^{2}\right)$ Test}

The purpose of testing predictive relevance $\left(\mathrm{Q}^{2}\right)$ is to validate the model. The results of the $\mathrm{Q}^{2}$ calculation are as follows:

$$
\begin{aligned}
& \mathrm{Q}^{2}=1-\left(1-\mathrm{R} 1^{2}\right)\left(1-\mathrm{R} 2^{2}\right) \\
& \mathrm{Q}^{2}=1-(1-0,307)(1-0,460) \\
& \mathrm{Q}^{2}=1-(0,693)(0,540) \\
& \mathrm{Q}^{2}=1-0,37422 \\
& \mathrm{Q}^{2}=0,62578
\end{aligned}
$$

Based on the predictive relevance $\left(\mathrm{Q}^{2}\right)$ calculation above, it shows a value of 0.625 . In this research model, endogenous latent variables have predictive relevance $\left(Q^{2}\right)$ values greater than 0 (zero) so that exogenous latent variables are suitable as explanatory variables that are able to predict their endogenous variables namely employee performance or in other words prove that this model is considered to have predictive good relevance.

\section{Evaluating the Path Coefficient / Hypothesis Test}

To evaluate the path coefficient, based on the results of calculations using calculate SmartPLS version 3.0 bootstrapping the path coefficient results obtained which illustrates the strength of the relationship between constructs / variables as shown in Table 9.

Table 9. Path Coefficient Test Results

\begin{tabular}{|l|l|l|l|l|l|l|}
\hline \multicolumn{1}{|c|}{ Indicators } & $\begin{array}{c}\text { Original } \\
\text { Sample } \\
(\mathbf{O})\end{array}$ & $\begin{array}{c}\text { Sample } \\
\mathbf{M} \text { Mean } \\
(\mathbf{M})\end{array}$ & $\begin{array}{c}\text { Standard } \\
\text { Deviation } \\
\text { (STDEV) }\end{array}$ & $\begin{array}{c}\text { T Statistics } \\
(\mathbf{O} / \text { STDEV) }\end{array}$ & $\begin{array}{c}\text { T } \\
\text { Table }\end{array}$ & $\begin{array}{c}\mathbf{P} \\
\text { Values }\end{array}$ \\
\hline $\begin{array}{l}\text { Workload > Job } \\
\text { Satisfaction }\end{array}$ & 0,144 & 0,140 & 0,062 & 2,326 & 1,96 & 0,020 \\
\hline Workload > WSC & 0,552 & 0,557 & 0,046 & 12,142 & 1,96 & 0,000 \\
\hline $\begin{array}{l}\text { POS > Job } \\
\text { Satisfaction }\end{array}$ & 0,639 & 0,644 & 0,058 & 11,087 & 1,96 & 0,000 \\
\hline POS > WSC & $-0,099$ & $-0,104$ & 0,055 & 1,795 & 1,96 & 0,073 \\
\hline $\begin{array}{l}\text { WSC - Job } \\
\text { Satisfaction }\end{array}$ & $-0,181$ & $-0,179$ & 0,063 & 2,880 & 1,96 & 0,004 \\
\hline
\end{tabular}

Source: researchers processed data (2019)

Based on table 9 it can be concluded that:

- Workload has an effect of 0.144 on Satisfaction with a T-Statistic value of 2.326 and PValues of 0.020 .

- Workload has an effect of 0.552 on WSC with a T-Statistic value of 12,142 and P-Values of 0,000 .

- PDO has an effect of 0.639 on Satisfaction with a T-Statistic value of 11,087 and P-Values of 0,000 .

- PDO has an effect of -0.099 on WSC with a T-Statistic value of 1.795 and P-Values of 0.073 . 
- WSC has an effect of -0.181 to Satisfaction with a T-Statistic value of 2.880 and P-Values of 0.004 .

So for the table $\mathrm{T}$ Value $(\mathrm{df} 2=265-4)$ alpha $0.05=1.96$

Explanation of the results of the calculation of the bootstrapping measurement model can be seen in Figure 3.

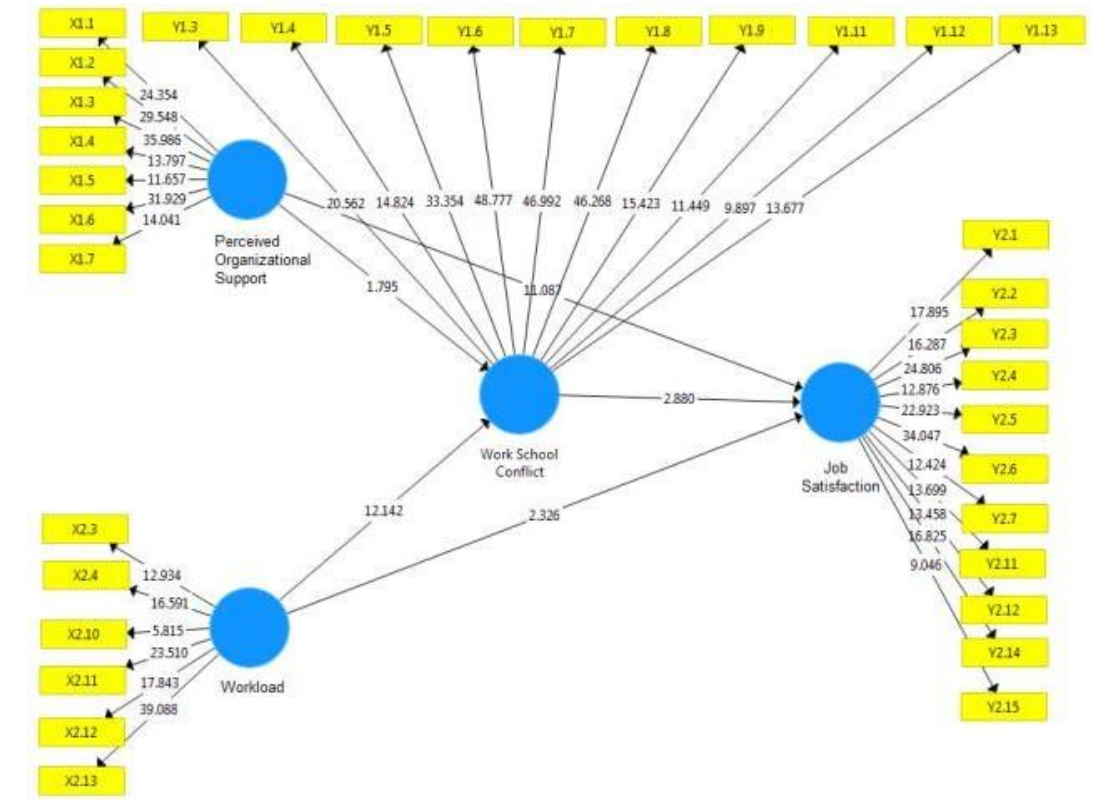

Figure 3. Bootstrapping Measurement Model Calculation Results

Source: researchers processed data (2019)

\section{Results of the Effect of Independent Variables on Dependent Variables}

Hypothesis testing about the influence between the exogenous variables of perceived organizational support $(\xi 1)$, workload $(\xi 2)$ on endogenous work school conflict $(\eta 1)$ variables both partially and simultaneously and also the perception of organizational support $(\xi 1)$, workload $(\xi 2)$ and work school conflict $(\eta 1)$ towards endogenous variables of job satisfaction $(\eta 2)$, and also the following are related to the effects of mediators or the influence of mediators in this case work motivation. The results of statistical calculations with the SmartPLS version 3.0 program are presented in Table 10 and Table 11 below.

Table 10. The Partial Effect of Independent Variables on Dependent Variables (Direct Effect)

\begin{tabular}{|l|l|l|l|l|l|}
\hline \multicolumn{1}{|c|}{ Indikator } & $\begin{array}{c}\text { Original } \\
\text { Sample } \\
(\mathbf{O})\end{array}$ & $\begin{array}{c}\text { Sample } \\
\text { Mean } \\
(\mathbf{M})\end{array}$ & $\begin{array}{c}\text { Standard } \\
\text { Deviation } \\
\text { (STDEV) }\end{array}$ & $\begin{array}{c}\text { T Statistics } \\
\text { (O/STDEV) }\end{array}$ & $\begin{array}{c}\text { P } \\
\text { Values }\end{array}$ \\
\hline $\begin{array}{l}\text { Workload (X2) > Job } \\
\text { Satisfacton (Y2) }\end{array}$ & 0,144 & 0,140 & 0,062 & 2,326 & 0,020 \\
\hline Workload (X2)- WSC (Y1) & 0,552 & 0,557 & 0,046 & 12,142 & 0,000 \\
\hline $\begin{array}{l}\text { POS (X1) > Job Satisfaction } \\
\text { (Y2) }\end{array}$ & 0,639 & 0,644 & 0,058 & 11,087 & 0,000 \\
\hline POS (X1) > WSC (Y1) & $-0,099$ & $-0,104$ & 0,055 & 1,795 & 0,073 \\
\hline $\begin{array}{l}\text { WSC(Y1) > Job } \\
\text { Satisfaction (Y2) }\end{array}$ & $-0,181$ & $-0,179$ & 0,063 & 2,880 & 0,004 \\
\hline
\end{tabular}

Source: Smart PLS 3.0 (2019) 
Table 11. Partial Effect of Independent Variables on Dependent Variables without Mediation Variables (Indirect Effect)

\begin{tabular}{|l|r|r|r|r|r|}
\hline \multicolumn{1}{|c|}{ Indikator } & $\begin{array}{c}\text { Original } \\
\text { Sample } \\
(\mathbf{O})\end{array}$ & $\begin{array}{c}\text { Sample } \\
\text { Mean } \\
(\mathbf{M})\end{array}$ & $\begin{array}{c}\text { Standard } \\
\text { Deviation } \\
\text { (STDEV) }\end{array}$ & $\begin{array}{c}\text { T Statistics } \\
(\mathbf{O} / \text { STDEV) }\end{array}$ & $\begin{array}{c}\mathbf{P} \\
\text { Values }\end{array}$ \\
\hline $\begin{array}{l}\text { Workload (X2) > Job } \\
\text { Satisfaction (Y2) }\end{array}$ & 0,055 & 0,067 & 0,070 & 0,785 & 0,433 \\
\hline $\begin{array}{l}\text { POS (X1) > Job Satisfaction } \\
\text { (Y2) }\end{array}$ & 0,651 & 0,651 & 0,053 & 12,311 & 0,000 \\
\hline
\end{tabular}

Source: Smart PLS 3.0 (2019)

The statistical calculation results obtained are presented in Table 10 and Table 11 for the structural model the following hypotheses are obtained:

\section{Hypothesis 1: Perceived Organizational Support has Effect to Job Satisfaction}

Obtained a path coefficient of 0.639 with a $\mathrm{p}$-value of 0,000 , thus $\mathrm{H}_{1}$ is accepted $(\mathrm{P}<0.05)$, Perceived Organizational Support has a positive and significant effect on Job Satisfaction. This is in line with what was said by Robbins (2008) that the higher the Perception of Organizational Support that occurs in the company, the higher the job satisfaction of employees.

According to Robbins (2008) perceived organizational support is the degree to which employees believe the organization appreciates employee contributions and cares about employee welfare. This shows that individuals feel the organization provides support when rewards are considered fairly, employees feel they have a voice in decision making and there is support from direct supervisors. If organizational support is positive and organizational commitment is strong, job satisfaction will increase.

This is in line with the results of previous studies conducted by Rifki \& Arijo (2015), Kneight \& Leimer (2010), Baranik et al, (2010), Kartika \& Sagung (2018) perceived organizational support has significant effect on job satisfaction.

\section{Hypothesis 2: Workload has Effect to Job Satisfaction}

Obtained a path coefficient of 0.144 with a p-value of 0.020 , thus $\mathrm{H}_{2}$ is accepted $(\mathrm{P}<0.05)$. Negative Workload on Job Satisfaction. This is consistent with research conducted by Purbaningrat and Surya (2015). Mahendrawan and Indrawati (2015) also found that workload had a negative and significant effect on employee job satisfaction.

\section{Hypothesis 3: Perceived Organizational Support has Effect to Work School conflict}

Obtained a path coefficient of -0.099 with a p-value of 0.073 , thus $\mathrm{H}_{3}$ is rejected $(\mathrm{P}>$ 0.05), Perception of Organizational Support has no effect on Work School. The research findings show that the perception of organizational support has no significant effect on work school conflict. This means that the presence or absence of support provided by the company to employees when continuing their Master degree studies has no effect in carrying out their study activities even though they have to perform multiple roles as employees and students.

This is not in line with the results of previous studies conducted by Babic (2015), Stinglhamber (2015), and Hansez (2015) where there is a positive relationship between the two variables. Perceptions of organizational support refer to employees' perceptions of the extent to which organizations value contributions, provide support, and care for their well-being 
(Rhoades \& Eisenberger, in Endah 2015).

\section{Hypothesis 4: Workload has Effect to Work School Conflict}

Obtained a path coefficient of 0.552 with a p-value of 0,000 , thus $\mathrm{H}_{4}$ is accepted $(\mathrm{P}<0.05)$, Workload does not have a significant positive effect on Work School Conflict. From Figure it can be seen that the dimensions of psychological burden are the most important dimensions after mediated by the Work School conflict variable. . The psychological burden dimension is the dimension that plays the most role after being mediated by the Work School conflict variable. That is, the high demands of responsibility given by the company to employees have an impact on the emergence of anxiety and anxiety when conducting lecture activities, employees think of work while conducting lecture activities. This has an impact on the increasing level of existing dual role conflict. This was found in a study conducted by Sohaib Raza et al 2017 which found that to reduce role conflict, the burden given to employees needs to be reduced according to the position held by the employee. Because the many double burdens held by employees have an impact on the high role conflict that occurs.

\section{Hypothesis 5: Work school conflict negatively has Effect to job satisfaction}

Obtained a path coefficient of -0.181 with p-values of 0.004 , thus $\mathrm{H}_{5}$ is accepted $(\mathrm{P}<0.05)$. Work school conflict has a significant positive effect on job satisfaction. From Figure 4.1 it can be seen that Work school conflict as a mediating variable has the dimension of strain based conflict as the most influential dimension in influencing job satisfaction. Based on the dimensions of strain based conflict, it can be seen that employees experience fatigue when studying due to work, demands of work make college assignments neglected, the emergence of feeling lazy lectures, job stress that interferes with concentration on college assignments and ignores college assignments. In a study found by Goodarzi (2015) found that the higher the role conflict that employees have, the lower the level of satisfaction they have as employees.

\section{Hypothesis 6: Perception of Organizational Support has Effect to Job Satisfaction through Work School Conflict.}

Based on table 10 the influence of independent variables and the dependent variable related to the influence of perceived organizational support for job satisfaction through work school conflict mediating variables obtained path coefficients of 0.639 with p-values of 0,000 while based on table 4.8 the influence of independent variables and dependent variables without mediating variables work school conflict obtained a path coefficient of 0.651 with a p-value of 0,000 . Based on the above data it can be seen that the mediating variable has a role of 0.012 in the path coefficient, which means that with the existence of work school conflict the positive influence of perceived organizational support for job satisfaction is increasing.

From the above data it can be seen that work school conflict plays a role in increasing the positive influence of perceived organizational support for workload so that $\mathrm{H}_{6}$ is accepted.

\section{Hypothesis 7: Workload has Effect to Job Satisfaction through Work School Conflict.}

Based on table 10 the influence of independent and dependent variables related to the influence of workload on job satisfaction through work school conflict mediating variables obtained path coefficient of 0.144 with p-values of 0.020 while based on table 4.8 the influence of independent variables and dependent variables without mediating variables work school conflict obtained path coefficient 0.055 with p-values of 0.433 . Based on the above data it can be seen that the mediating variable has a role of 0.089 in 
the path coefficient and 0.413 in the P-values which means that with the work school conflict the positive effect of the workload on job satisfaction decreases. From the above data it can be seen that work school conflict plays a role in reducing the negative influence of workload on job satisfaction so that $\mathrm{H}_{7}$ is accepted.

\section{CONCLUSION AND SUGGESTION}

Based on the results of the research and discussion in the previous chapters, several conclusions can be made as follows:

Perception of Organizational Support has a positive and significant effect on Job Satisfaction with a path coefficient of 0.639 with a p-value of 0,000 , thus $\mathrm{H}_{1}$ is accepted ( $p$ <0.05). The justice dimension is the most influential dimension in influencing job satisfaction with the work school conflict variable as a mediating variable.

Workload has a negative effect on Job Satisfaction with a path coefficient of 0.144 with a $\mathrm{p}$-value of 0.020 , thus $\mathrm{H}_{2}$ is accepted ( $\mathrm{p}<0.05$ ). The psychological burden dimension is the dimension that plays the most role in influencing job satisfaction with work school variables conflict as a mediating variable.

Perception of Organizational Support has no effect on Work School with a path coefficient of -0.099 with a p-value of 0.073 , thus $\mathrm{H}_{3}$ is rejected ( $\mathrm{p}>0.05$ ). The justice dimension is the dimension that plays the most role after being mediated by the Work School conflict variable.

Workload did not have a significant positive effect on Work School Conflict with a path coefficient of 0.552 with a $\mathrm{p}$-value of 0,000 , thus $\mathrm{H}_{4}$ was accepted $(\mathrm{p}<0.05)$. The psychological burden dimension is the dimension that plays the most role after being mediated by the Work School conflict variable.

Work school conflict has a significant positive effect on job satisfaction with a path coefficient of -0.181 with a p-value of 0.004 , thus $\mathrm{H}_{5}$ is accepted ( $\mathrm{p}<0.05$ ). The strain based conflict dimension is the most influential dimension in influencing job satisfaction. Work school conflict plays a role in increasing the positive influence of perceived organizational support on workload. path coefficient of perceived organizational support for job satisfaction through work school conflict mediating variables obtained a path coefficient of 0.639 with a p-value of 0,000 whereas without mediating variables work school conflict obtained a path coefficient of 0.651 with a p-value of 0,000 . From the path coefficient difference it is known that mediating variables play a role of 0.012 in the path coefficient, which means that with the existence of work school conflict the positive influence of perceived organizational support for job satisfaction is increasing.

Work school conflict plays a role in reducing the negative influence of workload on job satisfaction. Workload path coefficient on job satisfaction through work school conflict mediating variables obtained a path coefficient of 0.144 with a p-value of 0.020 while without work school conflict mediating variables obtained a path coefficient of 0.055 with a p-value of 0.433 . From the path coefficient difference it is known that mediating variables play a role of 0.089 in the path coefficient and 0.413 in the P-values which means that with the existence of work school conflict the negative effect of workload on job satisfaction decreases.

Based on the conclusion above, the researcher tries to convey some suggestions for further research. Based on the results of the above research, to improve employee job satisfaction, companies must have fair procedures in promotion of positions, listen to employee complaints and care for employee welfare. 
To increase job satisfaction of company employees need to provide sufficient support. One of the supports can be done by the company is by giving a lighter workload to employees who are continuing their Masters. Because by continuing Master's degrees, the employee helps the company in developing employee competencies and potential for the progress of the company.

Expectations from the authors for further research to dig deeper into the variables that affect work school conflict. Because research on work school conflict is very rare, moreover, more and more students are pursuing master's degrees. This will certainly be a very interesting study if carried out more deeply.

\section{REFERENCE}

Bakker, A. B.,\& Leiter, M. P. (2010).Work engagement: A handbook of essential theory and research. New York: Psychology Press.

Eisenberger, R., Stinglhamber, F., Vandenberghe, C., Sucharski, I., \&Rhoades, L. (2011). Perceived supervisor support: Contributions to perceived organizational support and employee retention. Journal of Applied Psychology , 87 , 565573.

Mahendrawan, I Gede dan Ayu Desi Indrawati. (2015). "Pengaruh Beban Kerja dan Kompensasi terhadap Kepuasan Kerja PT Panca Dewata Denpasar". Jurnal Manajemen Universitas Udayana, 4 (11), 3936-3961. Park, Y., \& Sprung, J. M. (2013). Work-school conflict and health outcomes: Beneficial 37, 376-403

Pranata, Sandi. (2016). "Pengaruh Beban Kerja, Konflik Kerja, dan Kompetensi terhadap Kepuasan Kerja pada Perusahaan Daerah Air Minum (PDAM) Tirta Bangka Sungailiat". Jurnal Manajemen Universitas Bangka Belitung.

Robbins, Stephen P. dan Timothy A. Judge. 2014. Perilaku Organisasi (organizational Behavior) Edisi ke-12. Jakarta: Salemba Empat.

Tarwaka., 2011. Ergonomi Industri. Dasar-dasar pengetahuan ergonomi dan aplikasi di tempat kerja. Solo: Harapan Press. 